\title{
Role of Trade Unions and Competitors on the Performance of Employees on Compensation Indirect (Case Study on Textile Company in East Java)
}

\author{
By.: ${ }^{1}$ Sundjoto $;{ }^{2}$ Pompong B. Setiadi $;{ }^{3}$ Murdijanto Purbangkoro \\ ${ }^{1}$ lecturerofS-1ManagementProgramandS-2ManagementMagisterProgram \\ ${ }^{2}$ lecturerofS-1ManagementProgramandS-2ManagementMagisterProgram \\ ${ }^{3}$ lecturerofS-1ManagementProgramandS-2ManagementMagisterProgram Higher Education of Economy \\ Science of MahardhikaSurabaya
}

\begin{abstract}
Objective research is trying to determine the influence of worker union and competitors against indirect compensation and employee performance testing technique where the data collection is the result of using Structural Equation Modeling with AMOS Ver 22.0 This research is conducted in some textile companies in East Java region. The amount of respondent taken for this research are 170 people from entire/all employees of textile company that become research subject. Beside use the primary data from interview with the respondent, in this research is used also secondary data obtained from document that exist in regional textile company in East Java. The scientific finding of this research indicate that worker union have correlation wtih the indirect compensation but did not have correlation wtih employee performance. While competitors variable did not have correlation with the indirect compensation and employee performance. Given the worker union is able to become a partner of the company, the company should be able to create the relationship is mutually beneficial to encourage the achievement of corporate goals.
\end{abstract}

Keyword: Labor union, competitors, indirect compensation and employee performance.

\section{Introduction}

Globalization of the world economy had an impact on a series of changes in all areas, both in terms of infrastructure and human resources. Changes in political and policy has brought Indonesia into tramsformasi and patterns of globalization of the world, especially with the development of communication technology. Change and upheaval is not just fast, unpredictable and complex, but also contradictory and could lead to a crisis. To respond to these changes companies need to fundamentally rethink the strategy, structure, their performance in order to have the ability to compete in an increasingly ketat.Perusahaan Competitors conditions required to be innovative and continually adjust its strategy planning related to changes in the business environment agara chosen strategy is always appropriate.

Competitors that exist today can be said to be competitors on the basis of the strength of the superior performance of companies that produce products of high competitiveness, because currently there is no single unit of product or service will be spared from competitors mainly textile products. In general, the textile industry products are standard products on the basis of comparative advantage in the form of a price advantage that relatively inexpensive because it uses cheap labor costs. The process of human resource management involves everyone, and it takes quite a bit. It also means to solve the problem existing while maintaining a long-term view and continue to improve ways of working so that the desired results can be obtained segera.Pemberian boost employment through the provision of compensation when it comes to performance management is necessary diperhatikanoleh. Success in work is basically influenced by two factors: individual factors and situational factors. Schuller (1997) suggests that basically the compensation is based on the elements of a competitor, human resources and performance assessment. Davis (2001) stated that the compensation will not be effective if it is not offset by the creation of a harmonious working climate. This involves a variety of activities and work which takes a strong will from the company and its employees in the form of willpower demonstrated by someone in implementing its business to the tasks of the job and the direction / purpose of this characteristic is supported by the efforts and determination of a person, who finally produce things that are profitable.

Motive or driving force that makes an individual to work according to Gibson (1997: 97) can be viewed from two aspects, namely intrinsic motivation and extrinsic motivation. Intrinsic motivation is motivation that drives individuals to work in order to get the award which is psychological, while extrinsic motivation is motivation that drives an individual to work in order to earn the award be physical such as salary, benefits, bonuses and others. 
With reference to the above opinion can be seen that basically the role of management to assess the exact motivations of employees to be able to work properly is very important, because by examining the motivations that serve as the basis of an employee to work, the management will be able to improve the quality of pelayaanannya to consumer.

Based on the above issues and findings revealed by earlier researchers, research problems can be formulated as follows:

1. Does the union variables significantly influence indirect compensation?

2. Is the union variables significantly influence employee performance?

3. Is the competitor variables significantly influence the indirect compensation?

4. Is the competitor variables significantly influence employee performance?

5. Does the variable compensation indirect significant influence on employee performance?

Objective, To test and analyze the role of trade unions and competitors to employee performance through indirect compensation on textile companies in East Java.Benefits Research, Empirically research is expected to be one of the basic considerations in the decision-making role of trade unions and competitors to employee performance through indirect compensation. In academic research is expected to contribute to further research to develop the factors that affect the performance of employees through indirect compensation.

\section{Review Of Theory}

Schuller (1997: 214) states that the factors affecting the provision of compensation include the external environment that consists of the labor market, labor unions, and competitors, internal environment consists of the life cycle of the organization, corporate culture, cultural diversity and business strategies as well as human resource activities consisting of job analysis, recruitment and selection, performance measurement and management relationship with the trade unions. Compensation output causing various companies such as productivity, competitive advantages, flexibility and quality of the work environment and it all comes down to the performance of the company.

The theory put forward by Schuller stated that the performance implications of the fulfillment of a series of requirements indicated in compensation or reward for its responsibility as well as part of the life satisfaction and also the output of the activities done during the process of the organization. Great remuneration or compensation and its composition is influenced by factors both internal and external in addition to human resource management process rooted in managerial policy. The expressed opinion of Schuller above, it can be seen that the internal and external environment as well as HR activities encourage the implementation of the evaluation of a system of rewards or compensation by the previous company where an evaluation of the compensation system is bringing some strategic choices in the form of a business relationship, the internal strategy, the similarity of external, administrative and the focus of the work is ultimately creates various forms of rewards for individual performance measures.

\section{External environment \\ 1. Labor Market}

The labor market influence the design of compensation in two ways. First, the level of labor Competitors partly determines the lower limit or the basic level of payments. Second, if the level of payments a company is too low qualified workers will not be willing to work in the company. Then the reduction in labor markets provide an opportunity for those who are qualified to fill the positions provided with the opportunity to negotiate the terms of employment are better.

\section{Unions}

The presence of unions in the private sector companies expected to raise wages 10 to 15 percent and raised the allowances of about 20 to 30 percent. Also the wage difference between companies that have unions seemed most during the recession period and the smallest during the period of inflation. Increased compensation costs in the company's existing trade union will realize higher yields, it is still much debated.

\section{Competitors}

Information from competitors in providing compensation to the employees need to be collected, and was made as benchmarks for comparison. Managers must be able to receive timely information about competitors and contact the firm intelligence to seek and find competitive information regarding compensation systems do it. In global markets, the important thing is the competitor orientation, the company should not be exaggerated emphasis on competition. Companies must manage a fine balance between employee monitoring and monitoring of competitors in the affairs of the compensation (Kotler 1997:217)

\section{performance theory}

Performance (performance) can be interpreted as a measure of the work in accordance with the rules and standards that apply to each organization's work. Simamora (1995: 327) states that the performance was an achievement of certain job requirements that ultimately are directly reflected in the resulting output quantity and quality. Output generated Simamora as stated above can be either physical or non-physical. 


\section{Factors that influence employee performance}

Performance in touch with one's attitude toward a certain psychological object, as claimed by Theodore (1991: 430) that "attitudes are importants consideration of workperformance. They accupy central position in the process of transforming work requirement in the effort ", thus it is known that attitude is a major consideration in order to achieve high performance when a positive attitude towards work, the achievement is also high, as well as to work prduktivitas too high. In general, the factors that drives the creation of optimal employee performance can be started from the human resources management that take into account the internal and external factors as well as attention to the fit between the organization and individual employees concerned. Basing on the above theoretical study, the researchers can develop a theoretical framework mapping as follows:

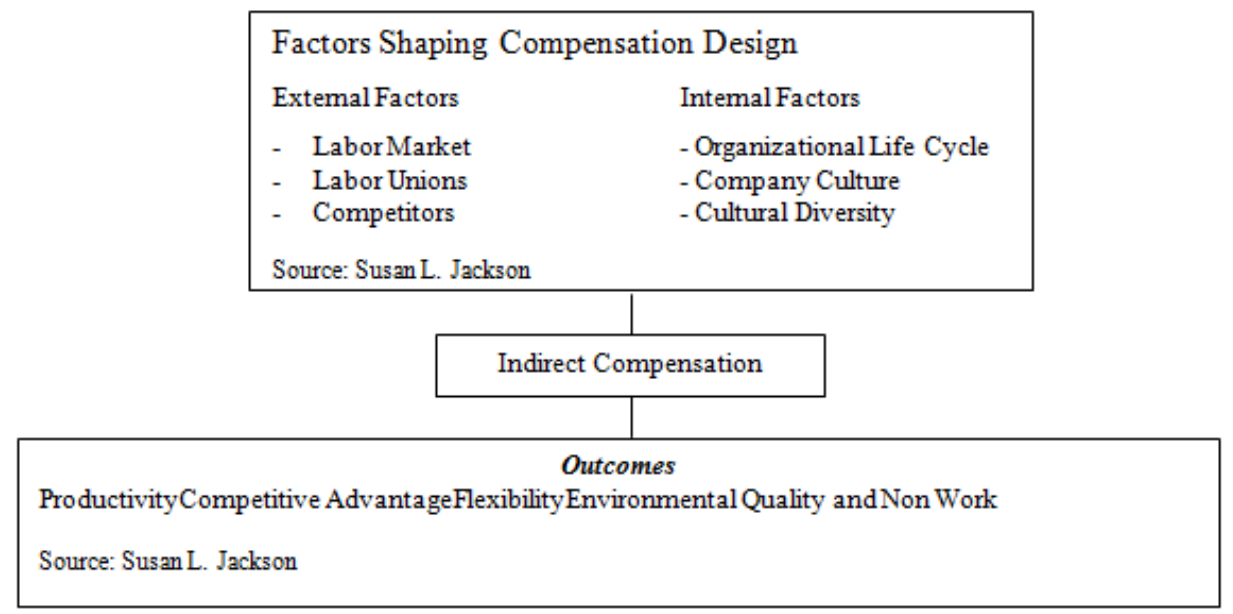

Figure 1. Mapping the theoretical framework

High level of concordance between the individual and the organization can be created through the process of fulfilling that causes productivity on the individual and not the organization, while to measure the level of individuals do not take into account all the interactions and complexity in the work process.Basing on theoretical study as mentioned above, it can be an understanding that the relationship created between the variable compensation with job satisfaction and employee performance is the direction in which the fulfillment of compensation in line with expectations and the duties and responsibilities of employees will generate certain level of satisfaction that have an impact on the creation of a certain level of employee performance.

\section{Research Methods}

The study population was taken by the target population, the company selected based textile company which already manufactures from raw materials processed into finished materials such as cloth and samples were taken a number of 3 companies that presented the textile industry in East Java. While respondents as resources to obtain primary data taken from the employee level employee, and the proportional composition of the four departments. The sampling technique used is clustered random sampling, where each level of management that have been grouped sampled proportionally to the total number of employees. Of the three textile factories that form the basis pengambikan samples, only two textile factories, namely PT. Mertex and PT. Coats Indonesia who are willing to be the subject penlitian.

Hair et al. in Ferdinand (2002: 48), states that the sample size depends on the number of indicators used in the entire latent variables. Stated that the minimum sample size is 5-10 observation for each parameter estimation. Based on these opinions, the minimum sample size in this study are: $\mathrm{n}=8 \mathrm{x}$ number of indicators, where $\mathrm{n}$ is the minimum number of samples. The indicators used in this study as many as 11 indicators, in order to obtain the minimum number of samples 88 respondents. In this case I used a sample of 170 respondents. Furthermore, as a sampling technique is done by random. To answer the problem formulation and testing of the hypothesis, then the data obtained will be processed in accordance with the needs analysis. For the sake of discussion, the data is processed and presented based on the principles of descriptive statistics, whereas for analysis and hypothesis testing approach was used inferential statistics. For the analysis technique used is Sturctural Equation Modeling (SEM) using AMOS (Analysis of Moment Structure). The use of SEM allows researchers to examine the relationship between complex variables and obtain an overall picture of the overall models. SEM can examine together (Bohlen, in Ghozali and Fuad, 2005: 3). 


\section{Research Result}

Measurement models are part of SEM models consisting of a latent variables (constructs) and some manifest variables (indicators) that describe the latent variables.

Table 1. Summary of test measurement models

\begin{tabular}{|l|l|l|l|}
\hline Variabel & Hubungan & Variabel & Estimate \\
\hline x1 & $<---$ & Labor Union & .868 \\
\hline x2 & $<---$ & Labor Union & .722 \\
\hline x3 & $<---$ & Labor Union & .657 \\
\hline x4 & $<---$ & Competitor & .862 \\
\hline x5 & $<---$ & Competitor & .888 \\
\hline x6 & $<---$ & Competitor & .845 \\
\hline x7 & $<---$ & Indirect compensation & .820 \\
\hline x8 & $<---$ & Indirect compensation & .674 \\
\hline x9 & $<---$ & Employee performance & .821 \\
\hline x10 & $<---$ & Employee performance & .868 \\
\hline x11 & $<---$ & Employee performance & .783 \\
\hline
\end{tabular}

Based on the calculation above table, All Loading Factor to be significant at alpha 5\%, this value is said to be valid for loading values above 0.60 .

\section{Compliance Test Model (Goodness-of-fit test)}

After testing the assumptions SEM and the result that the data used to qualify, then the analysis can be continued by fitness model and a significance test causality. Results of testing the suitability of the model are presented in the following table:

Table 2 Conformance Testing Model

\begin{tabular}{|l|l|l|l|l|}
\hline No & Goodness of fit & Cut - of - value & Hasil Pengujian & Keterangan \\
\hline 1 & Chi Square & Diharapkan kecil & 43.045 & fit \\
\hline 2 & Significance Probablility & $\geq 0,05$ & 0,263 & fit \\
\hline 3 & RMSEA & $\leq 0,08$ & 0,028 & fit \\
\hline 4 & GFI & $\geq 0,90$ & 0,959 & fit \\
\hline 5 & AGFI & $\geq 0,90$ & 0,928 & fit \\
\hline 6 & CMIN/DF & $\leq 2,00$ & 1,133 & fit \\
\hline 7 & TLI & $\geq 0,90$ & 0,991 & fit \\
\hline 8 & CFI & $\geq 0,95$ & 0,994 & fit \\
\hline
\end{tabular}

Based on calculations derived from Table 2, showed that the models are correct, it can be shown on the parameter values of parameters that meet the criteria Model Conformance Test.

\section{Causality test}

Summary path coefficient of causality test results can be seen in Figure 2. For the interpretation of each hypothesis and the path coefficient is based can be described as follows:

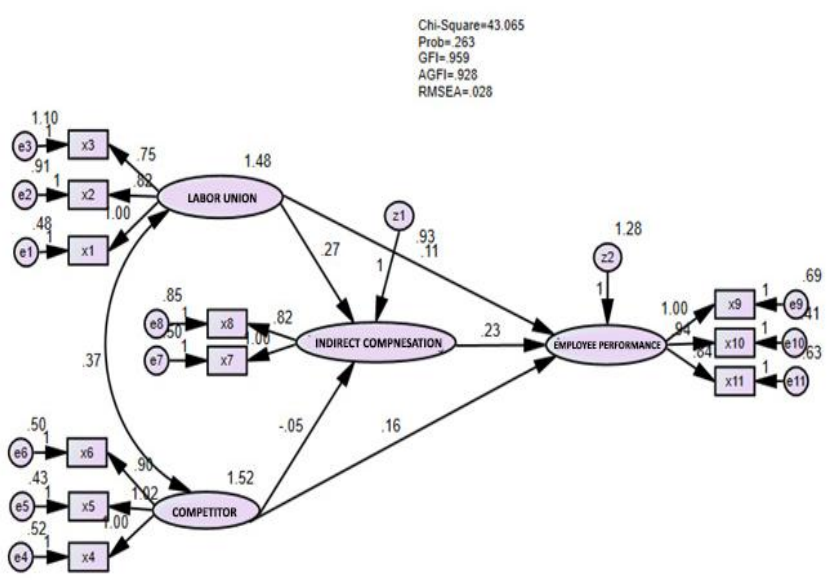

$\mathrm{S}=$ Significant at the level of $\alpha=0.05(5 \%)$

Figure 2. Test causality using AMOS Ver 22.0 


\section{hypothesis 1}

AMOS calculation results indicate that the union (X1) significantly with positive direction towards indirect compensation (Y). This is evident from the marked positive coefficient of 0.273 with CR values of 3.091 and acquired a significance probability (p) of 0.002 which is smaller than the specified significance level $\alpha$ of 0.05 . Thus the union variable effect on indirect compensation significantly. These results provide support for the hypothesis variables significantly influence the trade unions indirect compensation.

hypothesis 2

AMOS calculation results show that the union (X1) with no significant effect on employee performance (Y1). This is evident from a coefficient of 0.113 with CR values of 1.172 and acquired a significance probability (p) of 0.241 greater than the specified significance level $\alpha$ of 0.05 . These results do not provide support for the hypothesis unions have a significant effect on employee performance.

\section{hypothesis 3}

AMOS calculation results show that the competitor variable (X2) with no significant effect on indirect compensation (Y). This is evident from a coefficient of -0.051 with a CR value of -0642 and obtained a significance probability (p) of 0.521 greater than the specified significance level $\alpha$ of 0.05 . These results do not provide support for the hypothesis competitor significant effect on indirect compensation hypothesis 4

AMOS calculation results show that the competitor variable (X2) with no significant effect on employee performance (Y1). This is evident from a coefficient of 0.163 with CR values of 1.898 and acquired a significance probability (p) of 0.058 greater than the specified significance level $\alpha$ of 0.05 . These results do not provide support for the hypothesis competitors have significant influence on employee performance.

\section{hypothesis 5}

AMOS calculation results show that the indirect compensation (Y) significantly with positive direction on employee performance (Y1). This is evident from the marked positive coefficient of 0.231 with CR value of 1.801dan gained significance probability (p) of 0.022 which is smaller than the specified significance level $\alpha$ of 0.05 . Thus the variable compensation is not directly influenced by the performance of employees is 0.231 , which means every existing indirect compensation increases will raise the performance of employees amounted to 0.231 . These results provide support for the hypothesis of indirect compensation significant influence on employee performance.

\section{Discussion \\ 1. Unions influence on Indirect Compensation and Employee Performance}

Through the calculation of the indirect effect, as has been done before we got the result that the union has a stronger influence on the formation of compensation to the value of the indirect effects of 0273 compared to the performance of the employee or in other words the union was not able to produce or encourage employees in a companies to work better, being offset by planning a competitive compensation system that can be used as a basis for consideration for each employee to remain loyal to the company. The results of calculations performed by the researchers showed that these findings are consistent with the results of research Rooney (2001) which states that trade unions are often used as elements of pressure on the company in order to determine the amount of compensation where the findings generated by Rooney the effectiveness of unions in the form of components compensation in the range of 20-30 percent. For companies in Indonesia especially for the textile industry which tend to be labor-intensive, trade unions are often used as a means of control over the wage policy of the company.For companies, the unions were able to be a partner to give each of achieving the objectives nevertheless consider the ability of unions in addition to the company's financial capability is also a very important consideration. In connection with influential trade unions against indirect compensation that merupaka provision of the profits or other benefits for workers beyond the salary or wages remains a policy purely determined by the company and its ability in that division, so legally labor government and unions do not have role in setting policy on the provision of indirect compensation.

\section{Competitors influence on Indirect Compensation and Employee Performance}

The results of calculations performed by the researchers showed that these findings reject studies submitted by Schuler stating that a competitor has contributed to the determination of the amount of compensation to be received by the employee where the compensation effect on the provision of compensation in two ways. First, the level of labor Competitors partly determines the lower limit or floor level of payment. Second, if the level of payments a company is too low, workers who qualify will not be willing to work in the company. Three, reduction of labor market provides an opportunity to those who are qualified to fill the positions provided with the opportunity to negotiate the terms of employment better. In the conditions found in this study it appears that a competitor is used as the basis of monitoring of compensation but nevertheless the decision awarding compensation often does not refer to the results of monitoring at the competitor and more basing on the ability of companies and collective agreements between workers and companies. 


\section{Indirect Compensation influence on Employee Performance}

The findings of research done on some textile companies that are the subject of observation shows these results are consistent with research Shimp, (1997) in Yoo et al, (2000); Hauser and Wernerfeldt, (1990) who found that the direct and indirect compensation significantly related to performance because it can reinforce the encouragement of individual employees by fulfilling their needs. Managers at several textile companies observed agreed that indirect compensation can be used to motivate the performance of employees.In the expectations theory of motivation, people associate any behavior with the results and compensation or hukuman.Karena each person has different needs and perceptions, the results of such payment, promotions, strikes or work better to have different values for different people. So in considering which compensation will be used, a manager must be keen in observing individual differences. If compensation is used to motivate, they can produce a form of business in order to achieve to a high level. The assessment in accordance with the opinion delivered by Flippo (1985: 308) that the compensation directly or indirectly an important part in determining the performance, the determination of the amount of wages that need attention and carried out carefully so that the remuneration given can be a source of motivation to work, Determination of certain wage level is very important for the company, because it reflects the organization's efforts to maintain its human resources (Handoko, 1995: 155)

\section{Conclusion}

Based on testing relationships between variables obtained the following results:

1. The role of trade unions in fighting for the rights of employees, especially for the fulfillment of employees' rights in the form of indirect compensation is currently widely perceived contribution where companies often make the union as a partner in the formulation of compensation granted in compliance with the aza kentntuan government and the principles of justice,

2. The union did not influence the performance of employees, because until now the union is to function as a controller management policies that are related to the presence of the employee and not touched until his participation as a driver of employee and company performance.

3. Competitors do not have a role in shaping kompensassi indirectly will the company to its employees because, as with direct compensation, the determination of the amount and composition of indirect compensation is based more on the ability and the scope of business of the company concerned.

4. In the case of the employee's performance, as evidenced competitors are not able to drive increased performance for employees in which it is due to the employee's performance is the result of interaction between all the internal environment that automatically the level of employee performance is also determined from the interaction and parties the work involved in interactions.

\section{References}

[1]. Arikunto, Suharsimi, 2000, Procedures Penilitian, Publisher LP3ES, Jakarta

[2]. As'ad, Moch, 1995, Industrial Psychology, Canisius Publishers, Jakarta

[3]. Atmosoeprapto, Kisdarto, 2000, Productivity Actualization Culture Company, Moulds Second, PT Elex Media Komputindo, Jakarta.

[4]. Beeker, Brian and Gerhart, Barry, 1996, The Impact of Human Resource Management on Organizational Performance: Progress and Prospect Academy of Management Journal 39 (4).

[5]. Bowen, DE, Ledfor, GE Jr. 1996 Hiring for the Organization not the job. Academy of Management Executive. P. 35-51.

[6]. Cascio, Wayne, 1998, the Personnel Management and Human Resources Management, Prentice Hall, Inc. New Jersey

[7]. Central Bureau of Statistics, in 2001, Data Textile Industry (Manufacture Industries) in East Java, January

[8]. Davis, Keith, 1998, Organizational bahavior, Prentice Hall, Inc. New Jersey, 2001, Human Resources Management, Prentice Hall, Inc. New Jersey

[9]. Dessler. G. 1997. Human Resource Management. Indonesian edition. Volume II PT. Prehalindo: Jakarta

[10]. Durantio, Sugiarto and Sitinjak, 2001, Organizational Behavior and Human Resource Management, Publisher Andy, Jogjakarta

[11]. Ferdinand, Augustin, 2000, Organizational Climate at Work, Harvard Business Review, November-December, 2002, Structural Equation Modeling in Research Management. Applications Elaborate Models in Research for Master and Doctoral thesis, University of Diponegoro Publisher Agency

[12]. Flippo, Edwin, 1995, Personnel Management: International Student Edition, 6th Edition, McGraw-Hill Book Co., Singapore

[13]. Filipowski, 1991, Perspective: Is Pay Linked to Performance? Personnel Journal, Mei

[14]. French, Wendell, 1990, Human Resources Management, Kent Publishing, London

[15]. Gaspersz, Vincent, in 1998, Total Quality Management, Kent-Publishing, New Jersey.

[16]. Gibson, et al. 1996 Organizational Behavior, Structure and Process, Eighth Edition (Translation), Binarupa Literacy, Jakarta.

[17]. Gomes, Faustino, 1995, Human Resource Management, Publisher Andy, Jogjakarta

[18]. Hair, Joseph F Jr, Ralph Anderson E, Tathan Ronald L, and Black William C, 1998 Multivariate Data Analysis, 5th Edition, Prentice-Hall, Inc., Upper Saddle River, New Jersey.

[19]. Hair, Joseph F Jr, David A Aaker, 2000, 4th Edition Research Methodology, Prectice-Hall, Inc., Upper Saddle River, New Jersey.

[20]. Handoko, Hani, 1995, Introduction to Management; Publisher LP3ES, Jakarta.

[21]. Hauser \& Warnerfeld, 1990, Dimension of Work Satisfaction commitment as predictors of type Journal of Managerial Psychology

[22]. Hulin, Albert, 1996, Organizational Development: Behavior Science Interventions for Organization Improvement, Englewood Cliffs, N. J., Prentice-Hall, Inc.

[23]. Imam Ghozali, 2013, Concepts and Alpikasi with AMOS 22.0, Diponegoro University, Semarang 
[24]. Indrianto, Nur, Bambang Supomo, 1999 Business Research Methodology, For Accounting \& Management, First Edition, BPFE, Jogjakarta.

[25]. Kerlinger, Fred N., 1998, Principles of Behavioral Research, Moulds Sixth, Gajah Mada University Press, Jogjakarta.

[26]. Riduwan \& Sunarto, 2013, Introduction to Statistics for research, Alfabeta, Bandung

[27]. Singgih santoso, 2014, Basic Concepts and Alplikasi SEM with AMOS 22, Gramedia, Jakarta

[28]. Southern Heng, 2012, SEM concepts and applications using lisrel 8.80, Alfabeta, Bandung

[29]. Sugiyono, 2013, the statistics for research, Alfabeta, Bandung 